THE WAR FOR THE SEAS 


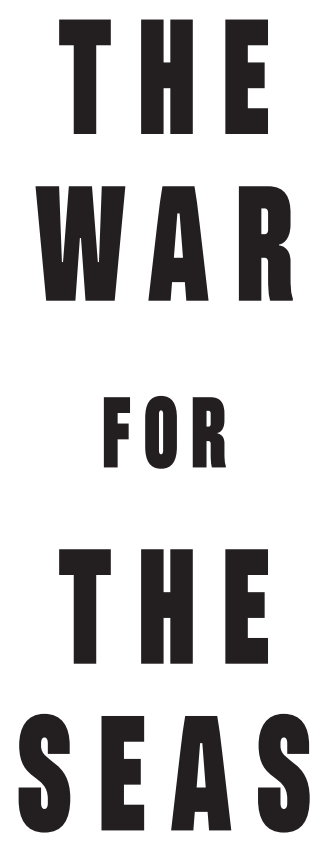

A MARITIME HISTORY OF WORLD WAR II

\section{EVAN MAWDSLEY}


Copyright (c) 2019 Evan Mawdsley

All rights reserved. This book may not be reproduced in whole or in part, in any form (beyond that copying permitted by Sections 107 and 108 of the U.S. Copyright Law and except by reviewers for the public press) without written permission from the publishers.

For information about this and other Yale University Press publications, please contact:

U.S. Office: sales.press@yale.edu yalebooks.com

Europe Office: sales@yaleup.co.uk yalebooks.co.uk

Set in Minion Pro Regular by IDSUK (DataConnection) Ltd

Printed in Great Britain by TJ International Ltd, Padstow, Cornwall

Library of Congress Control Number: 2019941052

ISBN 978-0-300-19019-9

A catalogue record for this book is available from the British Library.

10987654321

iv 
All freedom ... depends on freedom of the seas.

President Franklin D. Roosevelt, 27 May 1941 
